\author{
Gustavo A. Ospina-Tascón \\ Mauricio Umaña \\ William F. Bermúdez \\ Diego F. Bautista-Rincón \\ Juan D. Valencia \\ Humberto J. Madriñán \\ Glenn Hernandez \\ Alejandro Bruhn \\ César Arango-Dávila \\ Daniel De Backer
}

\section{Can venous-to-arterial carbon dioxide differences reflect microcirculatory alterations in patients with septic shock?}

Received: 8 August 2015

Accepted: 30 October 2015

Published online: 17 November 2015

(C) The Author(s) 2015. This article is published with open access at Springerlink.com

Take-home message: $\mathrm{Pv}_{\mathrm{aCO}}$ can reflect microcirculatory blood flow alterations during early stages of resuscitation in septic shock.

Electronic supplementary material The online version of this article (doi: 10.1007/s00134-015-4133-2) contains supplementary material, which is available to authorized users.

G. A. Ospina-Tascón ( $\bullet$ M. Umaña D. F. Bautista-Rincón · J. D. Valencia . H. J. Madriñán · C. Arango-Dávila Department of Intensive Care Medicine, Fundación Valle del Lili, Universidad ICESI, Cali, Colombia e-mail: gusospin@gmail.com Tel.: (+57).2.331.9090

\section{G. A. Ospina-Tascón · W. F. Bermúdez . C. Arango-Dávila}

Universidad del Valle, Escuela de Ciencias Básicas, Cali, Colombia

G. Hernandez · A. Bruhn

Departamento de Medicina Intensiva, Pontificia Universidad Católica de Chile, Santiago, Chile
D. De Backer

Intensive Care Department, CHIREC Hospitals, Université Libre de Bruxelles, Brussels, Belgium

Abstract Purpose: Septic shock has been associated with microvascular alterations and these in turn with the development of organ dysfunction. Despite advances in video microscopic techniques, evaluation of microcirculation at the bedside is still limited. Venous-to-arterial carbon dioxide difference $\left(\mathrm{Pv}-\mathrm{aCO}_{2}\right)$ may be increased even when venous $\mathrm{O}_{2}$ saturation $\left(\mathrm{SvO}_{2}\right)$ and cardiac output look normal, which could suggests microvascular derangements. We sought to evaluate whether $\mathrm{Pv}-\mathrm{aCO}_{2}$ can reflect the adequacy of microvascular perfusion during the early stages of resuscitation of septic shock. Methods: Prospective observational study including 75 patients with septic shock in a 60-bed mixed ICU. Arterial and mixed-venous blood gases and hemodynamic variables were obtained at catheter insertion (T0) and $6 \mathrm{~h}$ after (T6). Using a sidestream dark-field device, we simultaneously acquired sublingual microcirculatory images for blinded semiquantitative analysis. Pv-
$\mathrm{aCO}_{2}$ was defined as the difference between mixed-venous and arterial $\mathrm{CO}_{2}$ partial pressures. Results: Progressively lower percentages of small perfused vessels (PPV), lower functional capillary density, and higher heterogeneity of microvascular blood flow were observed at higher Pv$\mathrm{aCO}_{2}$ values at both T0 and T6. Pv$\mathrm{aCO}_{2}$ was significantly correlated to PPV (T0: coefficient $-5.35,95 \%$ CI -6.41 to $-4.29, p<0.001 ;$ T6: coefficient, $-3.49,95 \% \mathrm{CI}-4.43$ to $-2.55, p<0.001)$ and changes in Pv$\mathrm{aCO}_{2}$ between T0 and T6 were significantly related to changes in PPV $\left(R^{2}=0.42, p<0.001\right)$. Absolute values and changes in $\mathrm{Pv}-\mathrm{aCO}_{2}$ were not related to global hemodynamic variables. Good agreement between venous-to-arterial $\mathrm{CO}_{2}$ and $\mathrm{PPV}$ was maintained even after corrections for the Haldane effect. Conclusions: During early phases of resuscitation of septic shock, $\mathrm{Pv}$ $\mathrm{aCO}_{2}$ could reflect the adequacy of microvascular blood flow.

Keywords Septic shock . Venous-to-arterial carbon dioxide difference - Microcirculation . Microcirculatory blood flow 


\section{Introduction}

Septic shock remains associated with high mortality and early recognition of signs of tissue hypoperfusion is crucial in its management $[1,2]$. The usefulness of oxygenderived parameters as resuscitation targets has been strongly questioned [3] and recent data have failed to demonstrate clinical benefits [4-6]. Indeed, venous oxygen saturation $\left(\mathrm{SvO}_{2}\right)$ is often normal or near normal at admission to ICU [7]. Hence, other resuscitation goals such as venous-to-arterial carbon dioxide difference (Pv$\mathrm{aCO}_{2}$ ) have been proposed owing to their simplicity and ability to predict adverse clinical outcomes in patients achieving normal oxygen-derived parameters during the early phases of resuscitation of septic shock [8-10]. Nevertheless, the mechanisms implicated in the elevation of $\mathrm{Pv}-\mathrm{aCO}_{2}$ during inflammatory states are not completely understood and interpretation of $\mathrm{Pv}-\mathrm{aCO}_{2}$ values during resuscitation of septic shock could sometimes be difficult.

In cardiac arrest $\mathrm{Pv}_{-} \mathrm{aCO}_{2}$ increases as a result of vascular stagnation $[11,12]$. Similarly, $\mathrm{Pv}-\mathrm{aCO}_{2}$ and cardiac output are inversely related in experimental models of hemorrhagic, hypovolemic, and obstructive shock, highlighting the importance of blood flow in increasing venous $\mathrm{CO}_{2}$ [13-16]. Conversely, agreement between cardiac output variations and $\mathrm{Pv}-\mathrm{aCO}_{2}$ during septic shock is weak $[17,18]$, suggesting that macrohemodynamic alterations cannot explain such $\mathrm{Pv}^{-\mathrm{aCO}_{2}}$ variations $[8,9]$. Alternatively, $\mathrm{Pv}-\mathrm{aCO}_{2}$ could be related to tissue oxygenation derangements or oxygen consumption capabilities [13,14], but this concept was questioned when others demonstrated that ischemic but not hypoxic or anemic hypoxia leads to $\mathrm{Pv}-\mathrm{aCO}_{2}$ increments $[19,20]$. Hence, physiological variables different to macrohemodynamics and tissue dysoxia should be associated with variations of $\mathrm{Pv}-\mathrm{aCO}_{2}$ gradients during septic shock.

Microcirculatory derangements such as decreases in functional capillary density (FCD) and increased heterogeneity of blood flow are common findings in patients with severe sepsis and septic shock [21, 22], even when global oxygen parameters seem adequate. Importantly, these abnormalities might be associated with the development of multiple organ dysfunction and death [23] Nevertheless, despite improvements in techniques evaluating microcirculation at the bedside, immediate and reliable quantification of microcirculatory derangements is still limited. Thus, surrogates reflecting adequacy of microvascular blood flow might be highly valuable.

Tissue $\mathrm{CO}_{2}$ accumulation has been related to microcirculatory alterations $[24,25]$. However, the relationship between $\mathrm{Pv}-\mathrm{aCO}_{2}$ and microcirculatory derangements during human septic shock has not been widely studied. Since $\mathrm{Pv}-\mathrm{aCO}_{2}$ has been related to blood flow variations, but cardiac output seems insufficient to explain venous $\mathrm{CO}_{2}$ accumulation during septic shock $[8,9]$, we aimed to test the hypothesis that $\mathrm{Pv}-\mathrm{aCO}$ can reflect the adequacy of microvascular blood flow during the early stages of resuscitation in patients with septic shock.

\section{Materials and methods}

This prospective observational study was conducted in a 60-bed mixed ICU at a university hospital (Fundación Valle del Lili, Cali, Colombia) during 15 consecutive months (April 2012 to July 2013). We received approval from the Fundación Valle del Lili's ethical and biomedical research committee (protocol number 563, approval number 091-2012). The original version of the protocol is attached as Electronic Supplementary Material 2 (ESM 2). Written informed consent was waived as no new or invasive procedures were conducted for the study purposes. However, in all cases the patients and/or their relatives were informed about the study and were given the opportunity to refuse the use of their data. Infection was defined according to the Centers for Diseases Control and Prevention criteria [26], whereas septic shock followed the criteria of the American College of Chest Physicians/Society of Critical Care Medicine Consensus Conference [27]. All consecutive patients fulfilling diagnostic criteria of septic shock and elected by the attending physician to use a pulmonary artery catheter (PAC) within the $6 \mathrm{~h}$ from the first hypotensive episode were included in the study. The decision to use a PAC was exclusively taken by the attending physician according to the local protocols for hemodynamic monitoring. We did not include patients with a preceding episode of septic shock within the last 3 months, patients younger than 18 years old, pregnant women, patients with limitation of therapeutic effort orders, or severe chronic obstructive pulmonary disease. Patients using cardiac output monitoring systems other than PAC were not included. For assessment of microcirculation, we did not include patients who were under noninvasive mechanical ventilation or breathing with a face mask with high $\mathrm{FiO}_{2}$, or patients who were agitated or not collaborative when we first attempted to visualize sublingual microcirculation.

A STROBE statement checklist for observational studies is provided in ESM Table E4.

\section{General management}

Patients were managed according to an early resuscitation protocol modified from the Surviving Sepsis Campaign [28], with the aim of achieving (1) mean arterial pressure $\geq 65 \mathrm{mmHg}$; (2) urine output $\geq 0.5 \mathrm{ml} / \mathrm{kg} / \mathrm{min}$; (3) $\mathrm{SvO}_{2}$ $\geq 65 \%$; (4) normalization of lactate levels. Repeated fluid loads with crystalloids and/or albumin $4 \%$ guided by 
dynamic predictors of fluid responsiveness were performed in order to optimize cardiac preload. Dynamic predictors of fluid response were preferred over static parameters (i.e., pulmonary artery occlusion pressure or central venous pressure). However, when the use of dynamic predictors was not appropriate, cardiac filling pressures and clinical judgment were used to guide fluid administration. We did not use hydroxyethyl starches (HES). Norepinephrine was titrated to maintain mean arterial pressure (MAP) $>65 \mathrm{mmHg}$. Low doses of vasopressin titrated up to maximum of $0.03 \mathrm{IU} / \mathrm{min}$ were allowed to increase MAP or to decrease norepinephrine requirements but never as a single vasopressor. Dobutamine was titrated up to $20 \mu \mathrm{g} / \mathrm{kg} / \mathrm{min}$ when $\mathrm{SvO}_{2}$ goals were not achieved after fluid load optimization and normalization of MAP. Mechanical ventilation support was provided when needed under a targeted sedation and analgesia protocol with midazolam and fentanyl

Table 1 General characteristics

\begin{tabular}{|c|c|c|c|c|c|}
\hline & $\begin{array}{l}\text { All patients } \\
(n=75)\end{array}$ & $\begin{array}{l}\mathrm{Pv}-\mathrm{aCO}_{2}<6.0 \\
(n=39)\end{array}$ & $\begin{array}{l}\mathrm{Pv}-\mathrm{aCO}_{2}=6.0-9.9 \\
(n=25)\end{array}$ & $\begin{array}{l}\mathrm{Pv}-\mathrm{aCO}_{2} \geq 10.0 \\
(n=11)\end{array}$ & $p$ \\
\hline Age (years) & $67(58-77)$ & $66(60-74)$ & $73(65-81)$ & $54(43-71)^{*}$ & 0.02 \\
\hline Male (\%) & $45(60)$ & $23(59)$ & $15(60)$ & $7(64)$ & 0.96 \\
\hline APACHE II & $25(20-32)$ & $24(20-28)$ & $28(20-34)$ & $25(20-34)$ & 0.55 \\
\hline SOFA, day 1 & $11(8-15)$ & $10(6-15)$ & $11(9-15)$ & $11(10-14)$ & 0.22 \\
\hline $\begin{array}{l}\text { Time from first hypotension episode to } \\
\text { catheter insertion (h) }\end{array}$ & $3(3-4)$ & $3(3-4)$ & $4(2-4)$ & $3(2-4)$ & 0.69 \\
\hline Fluids before catheter insertion (ml) & $1650(1200-2400)$ & $1600(1200-2400)$ & $1600(1025-2300)$ & $2000(1500-2700)$ & 0.66 \\
\hline Temperature $\left({ }^{\circ} \mathrm{C}\right)$ & $37.5(37.4-38.4)$ & $37.4(37.2-38.2)$ & $37.8(37.6-38.4)$ & $37.6(37.5-38.6)$ & 0.54 \\
\hline Source of infection, $n(\%)$ & & & & & 0.25 \\
\hline Pneumonia & $30(40.0)$ & $18(46.2)$ & $10(40.0)$ & $2(18.2)$ & \\
\hline Abdominal & $17(22.7)$ & $8(20.5)$ & $7(28.0)$ & $2(18.2)$ & \\
\hline Urinary & $10(13.3)$ & $4(10.3)$ & $3(12.0)$ & $3(27.3)$ & \\
\hline Soft tissue & $2(2.7)$ & $2(5.1)$ & $0(0.0)$ & $0(0.0)$ & \\
\hline No specific site & $7(9.3)$ & $1(2.6)$ & $3(12.0)$ & $3(27.3)$ & \\
\hline Other & $9(12.0)$ & $6(15.4)$ & $2(8.0)$ & $1(9.1)$ & \\
\hline Medical, $n(\%)$ /surgical, $n(\%)$ & $48(64.0) / 27(36.0)$ & $25(64.1) / 14(35.9)$ & $15(60.0) / 10(40.0)$ & $8(72.7) / 3(27.3)$ & 0.76 \\
\hline Mechanical ventilation, $n(\%)$ & $57(76.0)$ & $34(87.2)$ & $24(96.0)$ & $9(81.8)$ & 0.37 \\
\hline Renal replacement therapy, $n(\%)$ & $12(16.0)$ & $7(17.9)$ & $3(12.0)$ & $2(18.2)$ & 0.80 \\
\hline
\end{tabular}

Values represent median (25-75th range) or absolute number $(\%)$ when indicated

$* p<0.05$ for $\mathrm{Pv}-\mathrm{aCO}_{2} \geq 10.0$ vs. ${\mathrm{Pv}-\mathrm{aCO}_{2}=6.0-9.9}$

Table 2 Microcirculatory blood flow variables for the predefined $\mathrm{Pv}-\mathrm{aCO}_{2}$ groups

\begin{tabular}{|c|c|c|c|}
\hline & $\begin{array}{l}\mathrm{Pv}-\mathrm{aCO} \mathrm{C}_{2}<6.0 \\
\left(n_{\mathrm{T} 0}=39\right)\left(n_{\mathrm{T} 6}=36\right)\end{array}$ & $\begin{array}{l}\mathrm{Pv}-\mathrm{aCO} \mathrm{CO}_{2}=6.0-9.9 \\
\left(n_{\mathrm{T} 0}=25\right)\left(n_{\mathrm{T} 6}=23\right)\end{array}$ & $\begin{array}{l}\mathrm{Pv}-\mathrm{aCO}_{2} \geq 10.0 \\
\left(n_{\mathrm{T} 0}=11\right)\left(n_{\mathrm{T} 6}=13\right)\end{array}$ \\
\hline \multicolumn{4}{|c|}{ PPV，\% } \\
\hline T0 & $83.9(74.2-93.2)^{* \dagger}$ & $56.8(47.9-62.9) \ddagger$ & $40.1(27.5-48.7)$ \\
\hline T6 & $85.5(77.8-92.3)^{* \dagger}$ & $61.7(54.5-74.5) \dagger$ & $43.2(33.7-49.6)$ \\
\hline \multicolumn{4}{|c|}{ LPV, \% } \\
\hline T0 & $100(97.0-100)^{* \dagger}$ & $96.0(91.2-100)$ & $90.0(80.0-100)$ \\
\hline T6 & $100(96.0-100) \dagger$ & $96.4(91.7-100)$ & $92.5(72.3-98.8)$ \\
\hline \multicolumn{4}{|l|}{ MFI } \\
\hline T0 & $2.4(2.1-2.9)^{* \dagger}$ & $1.6(1.2-1.9)$ & $1.4(1.1-1.9)$ \\
\hline T6 & $2.4(1.8-2.8)^{* \dagger}$ & $1.9(1.4-2.3) \dagger$ & $1.3(1.0-1.7)$ \\
\hline \multicolumn{4}{|c|}{$\mathrm{TCD}, \mathrm{n} / \mathrm{mm}^{2}$} \\
\hline $\mathrm{T} 0$ & $11.5(10.3-12.5) \dagger$ & $10.8(10.4-11.4)$ & $10.2(9.3-11.3)$ \\
\hline T6 & $11.5(10.3-13.3)^{*}$ & $10.1(8.9-10.8)$ & $10.8(9.8-11.6)$ \\
\hline \multicolumn{4}{|c|}{$\mathrm{FCD}, \mathrm{n} / \mathrm{mm}^{2}$} \\
\hline $\mathrm{T} 0$ & $7.8(6.2-9.6)^{* \dagger}$ & $4.9(4.4-5.9) \dagger$ & $3.4(1.4-4.9)$ \\
\hline T6 & $8.2(7.2-10.2)^{* \dagger}$ & $5.4(4.2-6.2) \ddagger$ & $4.7(3.2-5.6)$ \\
\hline \multicolumn{4}{|c|}{ Heterogeneity index } \\
\hline T0 & $0.24(0.10-0.51)^{* \dagger}$ & $0.46(0.33-0.63)$ & $0.57(0.29-1.04)$ \\
\hline T6 & $0.15(0.11-0.28)^{* \dagger}$ & $0.52(0.21-0.84)$ & $0.54(0.37-0.80)$ \\
\hline
\end{tabular}

$P P V$ percentage of small perfused vessels, $L P V$ percentage of large perfused vessels, $M F I$ microvascular flow index, TCD total capillary density, $F C D$ functional capillary density

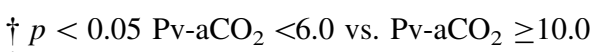

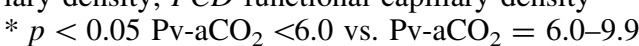



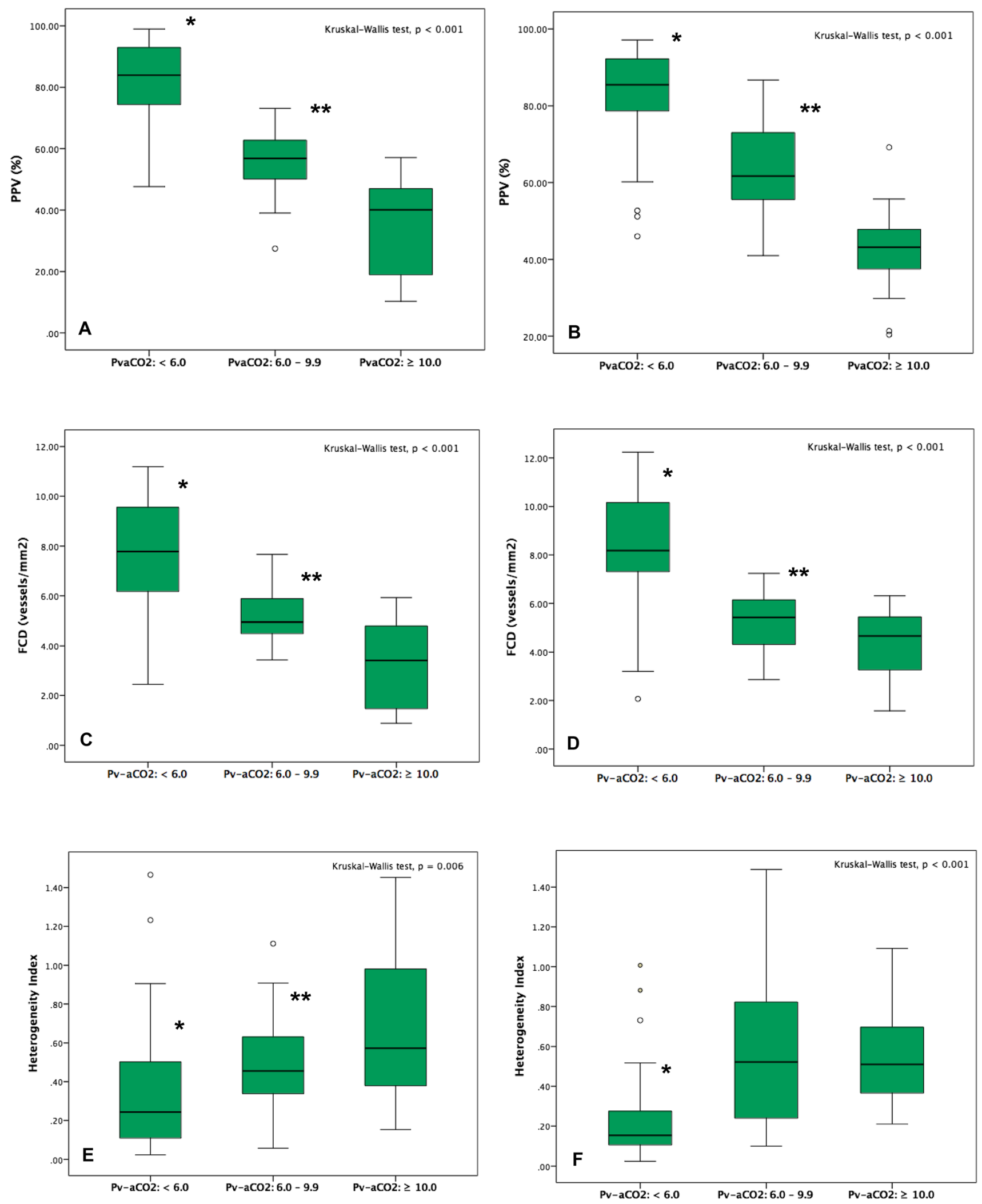
Fig. 1 Percentage of small vessels perfused (PPV), functional capillary density (FCD), and heterogeneity index (HI) for the predefined $\mathrm{Pv}-\mathrm{aCO}_{2}$ groups. Box plots depicting differences in $\mathrm{PPV}, \mathrm{FCD}$, and $\mathrm{HI}$ for predefined $\mathrm{Pv}-\mathrm{aCO}_{2}$ groups (group 1, $<6.0 \mathrm{mmHg}$; group 2, $6.0-9.9 \mathrm{mmHg}$; group $3, \geq 10 \mathrm{mmHg}$ ) at both T0 (a) and T6 (b). Kruskal-Wallis test, $p<0.001$. *Post hoc Mann-Whitney analysis adjusted for multiple comparisons; $p<0.05$ for group 1 vs. 2 and 1 vs. 3 , **post hoc Mann-Whitney analysis adjusted for multiple comparisons; $p<0.05$ for group 2 vs. 3. Boxes denote interquartile range, horizontal line in the boxes represents the median values, and whiskers extend 1.5 times the interquartile range above and below the 25th and 75th percentiles. $P P V$ percentage of small vessels perfused, $P v-a C \mathrm{O}_{2}$ venous-toarterial carbon dioxide difference, $F C D$ functional capillary density, $H I$ heterogeneity index

according to the local procedures. Use of low dose hydrocortisone (up to $200 \mathrm{mg} /$ day) was indicated in the case of persistence of vasopressor requirement despite ensuring an adequate intravascular volume. Glycemic control, venous thrombosis prophylaxis, and gastric ulcer stress prevention were provided according to Surviving Sepsis Guidelines [28].

\section{Study protocol}

All potentially eligible patients from the emergency room or clinical/surgical wards were screened by our "rapid response team" (which was available 24/7) and promptly transferred to the ICU where attending physicians decided on the type of hemodynamic monitoring needed. Those equipped with PAC monitoring were consecutively selected for inclusion. Time 0 (T0) was set when the PAC was inserted. Arterial and mixed venous blood samples were drawn for gases analysis (ABL300, Radiometer; Copenhagen, Denmark) at T0 and $6 \mathrm{~h}$ after (T6). We defined $\mathrm{Pv}-\mathrm{aCO}_{2}$ as the difference between mixed-venous and arterial $\mathrm{CO}_{2}$ partial pressures. Complete hemodynamic and respiratory parameters, inotropic/vasopressor doses, and volume of resuscitation fluids were also registered at these points. Simultaneously, sublingual microcirculation images were also recorded and stored under a random number for ulterior analysis [29].

\section{Microcirculatory measurements}

We used a sidestream dark-field (SDF) imaging device (MicroScan; MicroVision Medical, Amsterdam, the Netherlands) to explore microcirculation at T0 and T6. The SDF device was softly applied to the lateral side of the tongue covering an area of approximately $2.5-4 \mathrm{~cm}$ from the tip of tongue after gentle removal of secretions with gauze. At each measurement time, we recorded five sequences of video of $20 \mathrm{~s}$ each from different adjacent mucosa areas using a video card (Micro Video; Pinnacle system, Mountain Views, CA, USA). These sequences of video were stored under a random number and later analyzed by two investigators blinded to the origin of sequences (J.D.V. and G.O.T.). Vessels were classified as large or small using a cutoff value of $20 \mu \mathrm{m}$. Microvessels with continuous flow were considered as normal, whereas sluggish, intermittent, and stopped flows were considered as abnormal. In accordance with the consensus for the evaluation of microcirculation [29], we calculated the proportion of small perfused vessels $(<20 \mu \mathrm{m}$ diameter), the microvascular flow index (MFI), the heterogeneity index (HI), the total vascular density (all vessels), and the FCD (vessels $<20 \mu \mathrm{m}$ diameter). The intra- and interobserver variability were determined by using five sequences analyzed five times at 8-week intervals by two observers (J.D.V. and G.O.T.). We calculated the intra- and interobserver coefficient of variability for both the total number of vessels and the proportion of perfused vessels. An expanded description of image acquisition and analysis is provided in the ESM.

\section{Outcome measures}

The primary outcome was the agreement between $\mathrm{Pv}$ $\mathrm{aCO}_{2}$ and PPV at T0 and T6. Secondary outcomes included the relationships between $\mathrm{Pv}_{-} \mathrm{aCO}_{2}$ and hemodynamic systemic variables, and the relationships between changes in $\mathrm{Pv}-\mathrm{aCO}_{2}$ and changes in cardiac output and PPV observed between T0 and T6.

\section{Statistics}

As the primary hypothesis has not been tested before, it was difficult to compute a sample size. On the basis of previous data from our department [8], we estimated that 75 patients would provide a good range of dispersion of $\mathrm{Pv}_{-\mathrm{aCO}}$ and PPV for looking at relationship between variables.

Distribution of data was tested using the KolmogorovSmirnoff test. We explored the relationship between microcirculatory and systemic hemodynamic variables using the Spearman rho test and calculating the coefficient of determination $\left(R^{2}\right)$ to establish the strength of such associations. The distribution of microcirculatory variables, systemic hemodynamics, blood gases, and oxygen/tissue perfusion parameters at $\mathrm{T} 0$ and $\mathrm{T} 6$ was also evaluated for three predefined groups classified according to the $\mathrm{Pv}-\mathrm{aCO}_{2}$ range values in agreement with previous observations [8]: (1) $<6.0 \mathrm{mmHg}$ (2) $6.0-9.9 \mathrm{mmHg}$, and (3) $\geq 10 \mathrm{mmHg}$. Differences among groups were assessed using the Kruskal-Wallis test with post hoc MannWhitney analysis with adjustment for multiple comparisons.

We calculated the delta of variation of $\mathrm{Pv}_{\mathrm{aCO}}, \mathrm{PPV}$, and cardiac outputs between $\mathrm{T} 0$ and T6. Spearman rho test and $R^{2}$ were used to evaluate the agreement and 
strength between $\mathrm{Pv}-\mathrm{aCO}{ }_{2}$ vs. $\mathrm{PPV}, \mathrm{Pv}-\mathrm{aCO}_{2}$ vs. cardiac output, and PPV vs. cardiac output variations.

A multiple linear regression model was used to determinate the association between the $\mathrm{Pv}-\mathrm{aCO}_{2}$, cardiac index, $\mathrm{SvO}_{2}$, and mean arterial pressure with the percentage of small perfused vessels (PPV). Subsequent multiple linear regression models were constructed to test the relation between $\mathrm{Pv}-\mathrm{aCO}_{2}$ and the other systemic resuscitation goals with PPV in patients with $\mathrm{SvO}_{2}<65 \%$ or $\geq 65 \%$. The goodness of fit of each model was evaluated using the coefficient of determination. Through the Spearman rho test and calculating $R^{2}$, we also evaluated the agreement between PPV and $\mathrm{Pv}_{-} \mathrm{aCO}_{2}$, venous-to-arterial carbon dioxide content $\left(\mathrm{Cv}-\mathrm{aCO}_{2}\right)$, and venous-to-arterial carbon dioxide content to arterial-to-venous oxygen content ratio $\left(\mathrm{Cv}-\mathrm{aCO}_{2} / \mathrm{Da}-\mathrm{vO}_{2}\right)$.

Receiver operating characteristics (ROC) curves were constructed to compare the accuracy of $\mathrm{Pv}-\mathrm{aCO}_{2}$, lactate, $\mathrm{SvO}_{2}$, and cardiac output in predicting altered PPV at different abnormal cutoff points (PPV50, PPV60, and PPV70 \%). Areas under the ROC curves (AUCs) and their respective $95 \%$ confidence intervals (CIs) were calculated and compared using non-parametric statistics. Data are presented as median [percentiles 25-75]. A $p$ value of 0.05 or less (2-tailed) was considered significant.

\section{Results}

A total of 75 patients fulfilling the inclusion criteria were included in the study (ESM Fig. E1). General characteristics according to predefined $\mathrm{Pv}-\mathrm{aCO}_{2}$ groups are

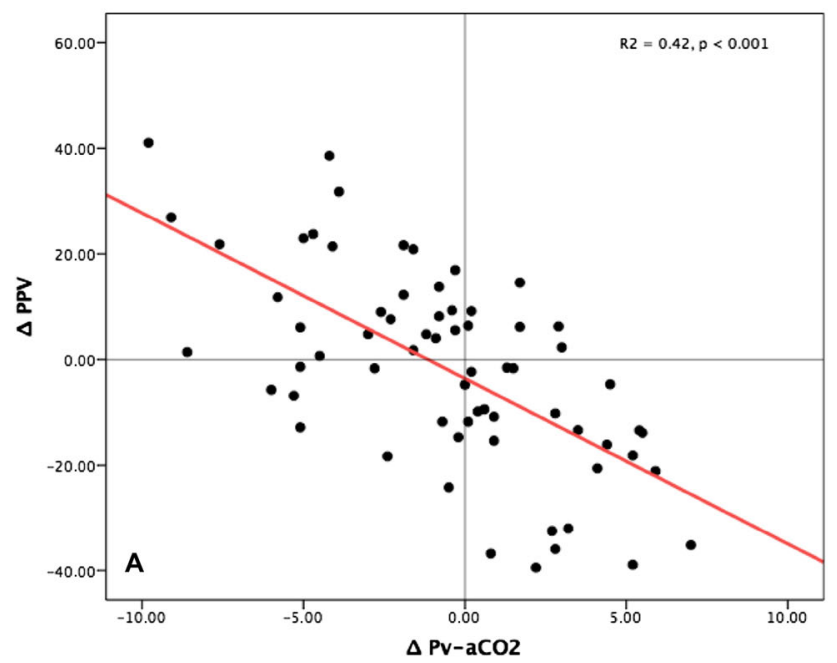

Fig. 2 Scatter plots showing the correlation of variations observed between changes in venous-to-arterial $\mathrm{CO}_{2}$ partial pressure differences $\left(\Delta \mathrm{Pv}-\mathrm{aCO}_{2}\right)$ and $\mathbf{a}$ changes in percentage of small vessels perfused $(\Delta \mathrm{PPV})$ between measurements performed at T0 and T6 presented in Table 1 . Mortality at day 28 in this cohort was $34.7 \%$ and the ICU length of stay was 6.0 (2.0-10.0) days. Time elapsed from first hypotension episode until PAC insertion and blood sampling (i.e., T0) was $3.0(3.0-4.0) \mathrm{h}$ and amount of fluids received at that point was $1650(1200-2400) \mathrm{ml}$.

A total of 39, 25, and 11 patients were assigned to the three predefined $\mathrm{Pv}_{\mathrm{aCO}}$ groups at $\mathrm{T} 0$, and 36, 23, and 13 at T6, respectively. Of these, $49 / 75$ patients $(65.3 \%)$ had $\mathrm{SvO}_{2}>65 \%$ at $\mathrm{T} 0$ and 58/72 (82.9\%) attained a $\mathrm{SvO}_{2}>65 \%$ at T6. Hemodynamic and respiratory variables, arterial and mixed-venous blood gases, and oxygen-derived parameters for the predefined $\mathrm{Pv}-\mathrm{aCO}_{2}$ groups at both T0 and T6 are shown in ESM Table E1.

Microcirculatory blood flow parameters are shown in Table 2. We observed a progressively lower PPV with a subsequent decrease in FCD and increased $\mathrm{HI}$ at progressively higher $\mathrm{Pv}_{-} \mathrm{aCO}_{2}$ values at both $\mathrm{T} 0$ and $\mathrm{T} 6$ (Fig. 1). Microcirculatory blood flow index (MFI) was also lower at higher $\mathrm{Pv}_{\mathrm{aCO}} \mathrm{aCO}_{2}$ values while total capillary density was normal only in patients with normal $\mathrm{Pv}_{-} \mathrm{CCO}_{2}$ (ESM Fig. E2). We observed a significant agreement between the ${\mathrm{PV}-\mathrm{aCO}_{2}}_{2}$ and PPV (T0: $R^{2}=0.61, p<0.001 ; \mathrm{T} 6$ : $R^{2}=0.55, p<0.001$; ESM Fig. E3). Conversely, we found lack of agreement between the cardiac index (representing the macro blood flow) and the PPV (ESM Fig. E4). Other resuscitation and hemodynamic goals such as $\mathrm{SvO}_{2}$ and MAP were also poorly correlated to the microcirculatory blood flow (ESM Figs. E5, E6).

Changes in $\mathrm{Pv}_{-} \mathrm{aCO}_{2}$ values between $\mathrm{T} 0$ and $\mathrm{T} 6$ were significantly related to changes in PPV, whereas changes in cardiac output were not related to changes in $\mathrm{Pv}_{-} \mathrm{aCO}_{2}$ or PPV (Fig. 2, ESM Fig. E7).

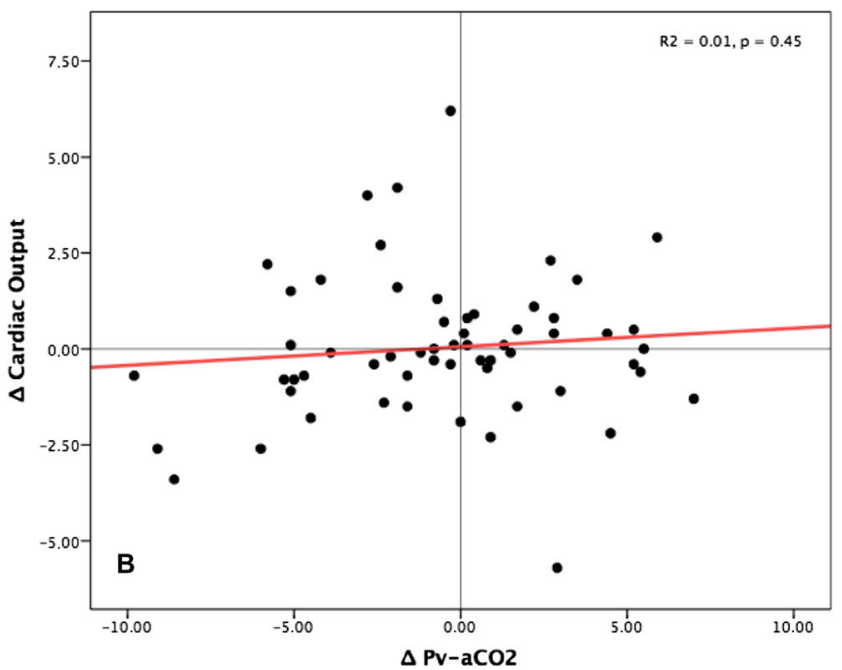

$\left(R^{2}=0.42, p<0.001\right)$ and $\mathbf{b}$ changes in cardiac output $(\Delta$ cardiac output) between measurements performed at T0 and T6 $\left(R^{2}=0.01, p=0.45\right)$ 
Table 3 Multiple linear regression models for variables related to the percentage of small perfused vessels (PPV)

\begin{tabular}{|c|c|c|c|c|c|c|c|c|}
\hline & \multicolumn{4}{|l|}{ T0 } & \multicolumn{4}{|l|}{ T6 } \\
\hline & Coefficient & $95 \% \mathrm{CI}$ & & $p$ value & Coefficient & $95 \% \mathrm{CI}$ & & $p$ value \\
\hline \multicolumn{9}{|l|}{ All patients } \\
\hline $\mathrm{Pv}-\mathrm{aCO}_{2}$ & -5.35 & -6.41 & -4.29 & $<0.001$ & -3.49 & -4.43 & -2.55 & $<0.001$ \\
\hline $\mathrm{SvO}_{2}, \%$ & 0.12 & -0.16 & 0.41 & 0.39 & 0.05 & -0.25 & 0.35 & 0.75 \\
\hline $\mathrm{CI}, \mathrm{L} / \mathrm{min}$ & -0.83 & -3.47 & 1.81 & 0.53 & -0.11 & -4.29 & 4.06 & 0.96 \\
\hline MAP & 0.23 & -0.04 & 0.51 & 0.93 & 0.30 & -0.04 & 0.64 & 0.08 \\
\hline$R^{2}$ for the model & - & - & - & 0.66 & - & - & - & 0.58 \\
\hline \multicolumn{9}{|l|}{$\mathrm{SvO}_{2} \geq 65 \%$} \\
\hline $\mathrm{Pv}-\mathrm{aCO}_{2}$ & -5.11 & -6.46 & -3.76 & $<0.001$ & -3.92 & -5.02 & -2.82 & $<0.001$ \\
\hline $\mathrm{CI}, \mathrm{L} / \mathrm{min}$ & -0.31 & -3.53 & 2.91 & 0.85 & 2.27 & -2.48 & 7.02 & 0.34 \\
\hline MAP & 0.32 & -0.03 & 0.63 & 0.06 & 0.19 & -0.21 & 0.59 & 0.34 \\
\hline$R^{2}$ for the model & - & - & - & 0.63 & - & - & - & 0.61 \\
\hline \multicolumn{9}{|l|}{$\mathrm{SvO}_{2}<65 \%$} \\
\hline $\begin{array}{l}\mathrm{Pv}-\mathrm{aCO}_{2} \\
\mathrm{CI}, \mathrm{L} / \mathrm{min}\end{array}$ & $\begin{array}{l}-5.91 \\
-2.18\end{array}$ & $\begin{array}{l}-1.03 \\
-7.37\end{array}$ & $\begin{array}{l}-4.19 \\
3.01\end{array}$ & $\begin{array}{c}<0.001 \\
0.39\end{array}$ & $\begin{array}{l}-3.22 \\
-3.68\end{array}$ & $\begin{array}{l}-5.39 \\
-13.43\end{array}$ & $\begin{array}{l}-1.05 \\
6.07\end{array}$ & $\begin{array}{l}0.007 \\
0.43\end{array}$ \\
\hline MAP & -0.07 & -0.65 & 0.52 & 0.82 & 0.39 & -0.35 & 1.13 & 0.28 \\
\hline$R^{2}$ for the model & - & - & - & 0.71 & - & - & - & 0.57 \\
\hline
\end{tabular}

$\mathrm{Pv}-\mathrm{aCO} \mathrm{O}_{2}$ venous to arterial carbon dioxide difference, $\mathrm{SvO}_{2}$ mixed venous oxygen saturation, $C I$ cardiac index, $M A P$ mean arterial pressure, $R^{2}$ coefficient of determination

A multiple linear regression model including all patients revealed that $\mathrm{Pv}-\mathrm{aCO}_{2}$ was independently related to PPV at T0 and T6, whereas other systemic hemodynamic parameters such as cardiac output, $\mathrm{SvO}_{2}$, or MAP were not significantly related to microcirculatory blood flow (Table 3). Likewise, when linear regression models were performed separately in patients with $\mathrm{SvO}_{2}<65 \%$ or $\mathrm{SvO}_{2} \geq 65 \%, \mathrm{Pv}-\mathrm{aCO}_{2}$ was again the only variable related to PPV at both T0 and T6 (Table 3).

Even though $\mathrm{Pv}-\mathrm{aCO}_{2}$ was apparently not correlated with cardiac index in this septic shock group (ESM Fig. E8), we observed lower cardiac indexes in predefined groups with abnormal $\mathrm{Pv}_{-} \mathrm{aCO}_{2}$ values at T6 (ESM Fig. E9). Similarly, lower MAP was observed in groups with higher $\mathrm{Pv}_{-} \mathrm{aCO}_{2}$ values at T6 (ESM Fig. E10). We also observed a trend towards lower $\mathrm{SvO}_{2}$ at higher $\mathrm{Pv}$ $\mathrm{aCO}_{2}$ values, without achieving significant differences (ESM Fig. E11).

$\mathrm{Pv}-\mathrm{aCO}_{2}$ exhibited the highest area under the ROC curve (AUC) for predicting abnormal PPV at different cutoffs at both T0 and T6. Other macrohemodynamic or tissue perfusion parameters were not related to PPV (ESM Fig. E12, Table E2).

Venous-to-arterial carbon dioxide differences calculated in terms of partial pressures $\left(\mathrm{Pv}-\mathrm{aCO}_{2}\right)$ were significantly related to those calculated by blood contents $\left(\mathrm{Cv}-\mathrm{aCO}_{2}\right)\left(\mathrm{T} 0: R^{2}=0.52, p<0.001 ; \mathrm{T} 6: R^{2}=0.42\right.$, $p<0.001$ ) (ESM Fig. E13). In addition to the significant relation between PPV and $\mathrm{Pv}-\mathrm{aCO}_{2}$, we also observed a linear relationship between PPV and $\mathrm{CV}_{-}-\mathrm{aCO}_{2}$ (T0: $R^{2}=0.42, p<0.001$, T6: $\left.R^{2}=0.32, p<0.001\right)$ and between PPV and the $\mathrm{Cv}-\mathrm{aCO}_{2} / \mathrm{Da}-\mathrm{vO}_{2}$ ratio (T0: $R^{2}=0.18, p<0.001$ ) (Fig. 3, ESM Fig. E14).
When data were analyzed considering the $\mathrm{Pv}_{\mathrm{aCO}}$ as a dependent variable, PPV was independently related to

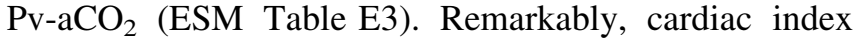
was also related to $\mathrm{Pv}-\mathrm{aCO}_{2}$ but only in patients with $\mathrm{SvO}_{2}<65 \%$ at T6 (ESM Table E3).

\section{Discussion}

Our observations reveal that $\mathrm{Pv}-\mathrm{aCO}_{2}$ is closely related to microcirculatory blood flow parameters during the early phases of resuscitation of septic shock. Indeed, $\mathrm{Pv}_{-} \mathrm{aCO}_{2}$ was the best predictor of the microvascular blood flow maldistribution as indicated by the alterations in the percentage of small vessels perfused, the heterogeneity blood flow index, and consequently FCD. In addition, changes in $\mathrm{Pv}-\mathrm{aCO}_{2}$ were significantly related to changes in PPV. Meanwhile, $\mathrm{Pv}-\mathrm{aCO}_{2}$ was poorly related to systemic hemodynamic variables.

Microcirculatory dysfunction in septic shock is a generalized phenomenon characterized by decreasing FCD associated with increasing heterogeneity of blood flow consisting in zones with well-perfused vessels adjacent to non-perfused capillaries [21, 22]. Those derangements seem to trigger the development of organ dysfunctions because capillary blood flow alterations precede cellular stress $[30,31]$ and hypoxia-inducible gene expression [32]. In fact, microcirculatory alterations are stronger determinants of outcomes than global hemodynamic parameters, with progressive increase in the risk of death in quartiles representing more severe microcirculatory disturbances [33]. Nevertheless, some 

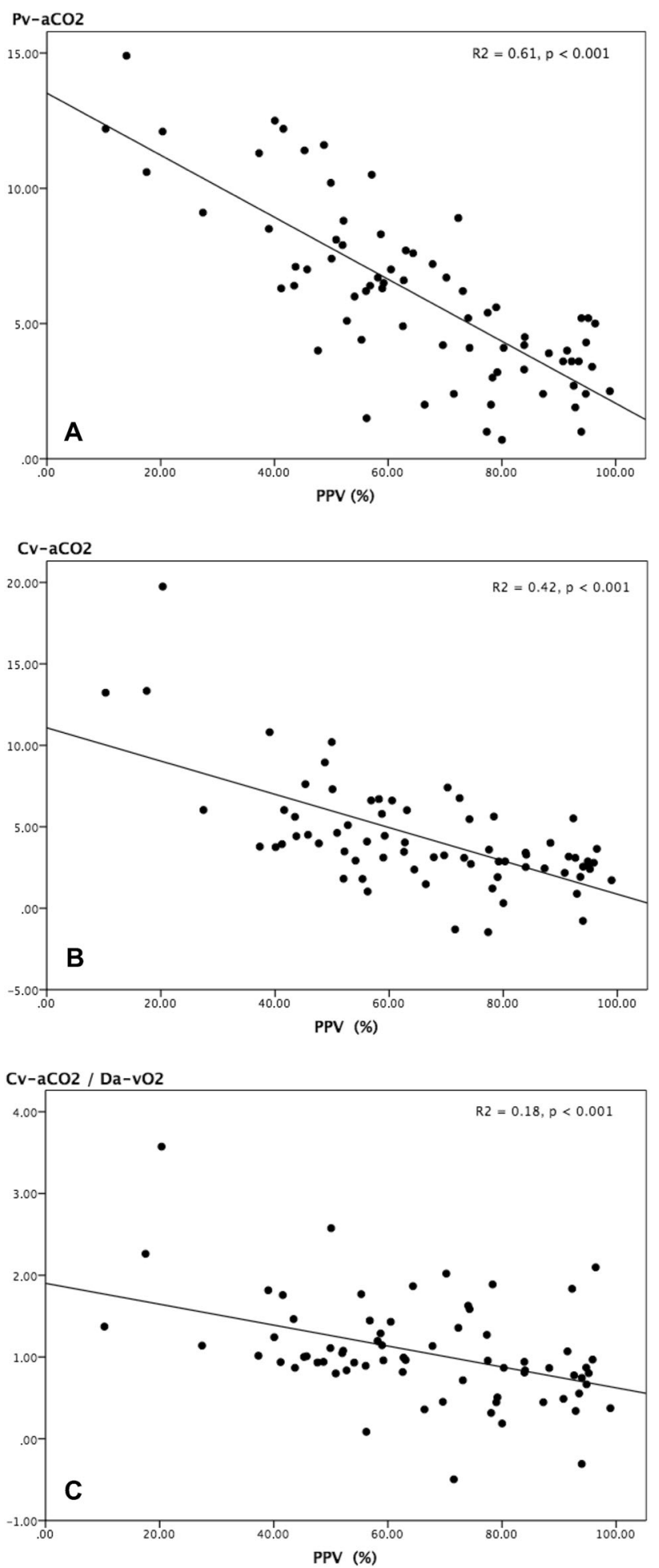

Fig. 3 Scatter plots depicting the relationships between the percentage of small vessels perfused (PPV) at T0 and a the venous-to-arterial $\mathrm{CO}_{2}$ partial pressure difference $\left(\mathrm{Pv}-\mathrm{aCO}_{2}\right)$, b the venous-to-arterial $\mathrm{CO}_{2}$ content difference $\left(\mathrm{Pv}-\mathrm{aCO}_{2}\right)$, and $\mathbf{c}$ the venous-to-arterial $\mathrm{CO}_{2}$ to arterial-venous $\mathrm{O}_{2}$ content difference ratio $\left(\mathrm{Cv}-\mathrm{aCO}_{2} / \mathrm{Da}-\mathrm{vO}_{2}\right)$. Coefficient of determination $\left(R^{2}\right)$ was calculated to assess the strength of correlations authors argue against microcirculatory dysfunction as the primary event leading to organ failure because microcirculatory derangements might be coupled with cellular and mitochondrial dysfunction and merely reflect an adaptive response [34]. Despite controversies about the causal relationship between microcirculatory alterations and organ dysfunction, the quest for appropriate monitoring of microcirculation could potentially improve resuscitation results in septic shock. However, despite advances in the techniques to evaluate microcirculation at the bedside, an immediate and reliable method to quantify microcirculatory alterations is not yet available [35]. In our study, $\mathrm{Pv}$ $\mathrm{aCO}_{2}$ was independently related to PPV (and consequently to FCD and MFI) at both T0 and T6, and this relationship was also maintained when we evaluated separately patients with $\mathrm{SvO}_{2}<65 \%$ or $\geq 65 \%$. Furthermore, $\mathrm{Pv}-\mathrm{aCO}_{2}$ was better at predicting abnormal PPV values at different cutoffs, and it was superior to macrohemodynamic or oxygen metabolism goals. Similarly, $\mathrm{Pv}-\mathrm{aCO}_{2}>6.0$ was related to an increased $\mathrm{HI}$ and therefore a decreased FCD. In normal conditions, the heterogeneity of microvascular blood flow is negligible [36], and matching of perfusion to metabolism usually improves during hypoxic or low flow states [37]. However, increases in the heterogeneity of the microcirculatory blood flow with the subsequent reduction in the FCD could be responsible for altered oxygen extraction capabilities in sepsis [38]. In fact, the heterogeneous flow cessation of individual capillaries could be an important factor determining the oxygen supply dependence phenomenon during the most severe cases of septic shock [38, 39] and this heterogeneity of microvascular blood flow could be tracked by $\mathrm{Pv}-\mathrm{aCO}_{2}$ variations during the early stages of resuscitation. In fact, changes observed in $\mathrm{Pv}^{-} \mathrm{aCO}_{2}$ between $\mathrm{T} 0$ and $\mathrm{T} 6$ were significantly related to those exhibited by PPV during the same time interval.

It has been suggested that microcirculatory derangements can occur in the absence of macrohemodynamic derangements even when global oxygen delivery seems adequate [21, 40]. However, other small-sized studies have insinuated that microcirculatory impairment is related to decreasing mean arterial pressure or increasing dose of vasopressors [41]. Our data also suggest some independence between microcirculatory variables and macrohemodynamics, which is in line with previous observations $[32,39]$. Indeed, changes exhibited by $\mathrm{Pv}$ $\mathrm{aCO}_{2}$ between $\mathrm{T} 0$ and $\mathrm{T} 6$ were not related to variations in cardiac output. Nevertheless, patients with a $\mathrm{Pv}-\mathrm{aCO}_{2}$ $\geq 6.0$ exhibited a trend toward lower cadiac index and MAP values than those with $\mathrm{Pv}-\mathrm{aCO}_{2}<6.0$. Furthermore, cadiac index was significant but weakly related to $\mathrm{Pv}$ $\mathrm{aCO}_{2}$ in patients with $\mathrm{SvO}_{2}<65 \%$ but not in those with normal $\mathrm{SvO}_{2}$.

$\mathrm{Pv}_{\mathrm{aCO}}$ can also be influenced by the $\mathrm{CO}_{2}$ dissociation curve. In this regard, we observed a good agreement 
between $\mathrm{Pv}-\mathrm{aCO}_{2}$ and the venous-to-arterial $\mathrm{CO}_{2}$ content difference $\left(\mathrm{Cv}-\mathrm{aCO}_{2}\right)$, especially at normal ranges of $\mathrm{Pv}$ $\mathrm{aCO}_{2}$ (i.e., $\mathrm{Pv}-\mathrm{aCO}_{2}<6.0 \mathrm{mmHg}$ ). Interestingly, $\mathrm{Cv}$ $\mathrm{aCO}_{2}$ was mostly dispersed at higher $\mathrm{Pv}-\mathrm{aCO}_{2}$ values, suggesting a deeper impact of the Haldane effect at abnormal $\mathrm{Pv}-\mathrm{aCO}_{2}$ values. Similarly, difference between slopes described by the linear regression of PPV vs. Pv$\mathrm{aCO}_{2}$ and PPV vs. $\mathrm{Cv}-\mathrm{aCO}_{2}$ relationships should also be influenced by the Haldane effect. Nevertheless, the also significant relationship between PPV vs. $\mathrm{Cv}-\mathrm{aCO}_{2}$ suggests that $\mathrm{CO}_{2}$ accumulation is, at least in part, related to the abnormal microcirculatory blood flow occurring during inflammatory conditions.

It has been recently suggested that combination of venous-to-arterial $\mathrm{CO}_{2}$ content to arterial-venous $\mathrm{O}_{2}$ difference ratio $\left(\mathrm{Cv}-\mathrm{aCO}_{2} / \mathrm{Da}-\mathrm{vO}_{2}\right)$ can add prognostic value to lactate measurements during early stages of septic shock [42] because it could be used as a surrogate for the $\mathrm{VCO}_{2} / \mathrm{VO}_{2}$ ratio (i.e., the respiratory quotient), to potentially detect non-aerobic $\mathrm{CO}_{2}$ generation [43]. We explored the association between the $\mathrm{Cv}-\mathrm{aCO}_{2} / \mathrm{Da}-\mathrm{vO}_{2}$ ratio and microcirculatory alterations; although, we found a significant correlation, the strength of such a relationship was notoriously weaker than that observed between $\mathrm{Pv}^{-} \mathrm{aCO}_{2}$ (or even $\mathrm{Cv}-\mathrm{aCO}_{2}$ ) and PPV. We acknowledge that the $\mathrm{Cv}-\mathrm{aCO}_{2} / \mathrm{Da}-\mathrm{vO}_{2}$ ratio could be subjected to more error in calculations than $\mathrm{Pv}_{-} \mathrm{aCO}_{2}$, but differences in the slope of the $\mathrm{Cv}-\mathrm{aCO}_{2} / \mathrm{Da}-\mathrm{vO}_{2}$ ratio vs. PPV compared with the $\mathrm{Pv}-\mathrm{aCO}_{2}$ vs. PPV relationship suggest the involvement of other physiological variables different to microcirculatory blood flow. Indeed, the $\mathrm{Cv}-\mathrm{aCO}_{2} / \mathrm{Da}$ $\mathrm{vO}_{2}$ ratio was abnormally increased in a number of patients through a wide range of PPV values. Therefore, it is not surprising that the $\mathrm{Cv}-\mathrm{aCO}_{2} / \mathrm{Da}-\mathrm{vO}_{2}$ ratio is superior to the $\mathrm{Pv}-\mathrm{aCO} / \mathrm{Da}-\mathrm{vO}_{2}$ ratio in the clinical setting [41] because under hypoxic conditions, disparity between $\mathrm{Pv}-\mathrm{aCO}_{2}$ and $\mathrm{Cv}-\mathrm{aCO}_{2}$ increases, and when coupling $\mathrm{Pv}-$ $\mathrm{aCO}_{2}$ to different $\mathrm{DO}_{2} / \mathrm{VO}_{2}$ values, $\mathrm{pH}$, temperature, and hemoglobin levels, the $\mathrm{Pv}-\mathrm{aCO}_{2} / \mathrm{Da}-\mathrm{vO}_{2}$ may acquire different cutoff normality values (a situation obviated when the numerator is corrected with the determinants of the Haldane effect).

We recognize limitations to our study. First, we used mixed venous blood to assess $\mathrm{Pv}-\mathrm{aCO}_{2}$ gradients, thus our results may not apply to central venous blood $\mathrm{Pv}_{-} \mathrm{aCO}_{2}$ gradients. Indeed, even though a reasonable agreement is often reported in trials comparing both sampling sites
[44], significant discrepancy can sometimes be observed and should not be neglected. Of note, this concordance between sampling sites has mostly be evaluated for $\mathrm{SvO}_{2}$ more than for $\mathrm{PCO}_{2}$ gradients. Second, variations of $\mathrm{Pv}-$ $\mathrm{aCO}_{2}$, macrohemodynamics, and microcirculatory variables between $\mathrm{T} 0$ and $\mathrm{T} 6$ were not the result of targeted interventions but simply changed during resuscitation. Nevertheless, relationships exhibited between $\mathrm{Pv}_{-} \mathrm{aCO}_{2}$ and PPV allow us hypothesize that some specific therapeutic interventions modifying microcirculation might reliably be tracked by $\mathrm{Pv}-\mathrm{aCO}_{2}$. Third, the relationship observed between microcirculatory variables and $\mathrm{Pv}$ $\mathrm{aCO}_{2}$ does not establish a causal association even though the physiological reasoning leading to our conclusions seems logical. Finally, there was no pre-experimental statistical plan published in a prespecified registry or a journal. However, observational research is, by nature, exploratory and requires considerable flexibility to explore novel findings and unexpected signals in the data $[45,46]$.

In conclusion, increased $\mathrm{Pv}-\mathrm{aCO}_{2}$ values are associated with microcirculatory dysfunction in septic shock, even when $\mathrm{SvO}_{2}$ is within normal values. Whether changes in $\mathrm{Pv}-\mathrm{aCO}_{2}$ can be used to track changes in microvascular perfusion remains to be determined.

Acknowledgments The authors thank Dr. Jairo Osorno and Dr. Fernando Rosso (CIC, Fundación Valle del Lili-Universidad ICESI, Cali, Colombia) for their contribution to enhancing the quality of the manuscript. The authors also thank Dr. Yuri Takeuchi and Dr. Marcela Granados (Fundación Valle del Lili-Universidad ICESI) for their unconditional support to this project.

\section{Compliance with ethical standards}

Funding Tecnoquímicas S.A. (Colombia)-Centro Investigaciones Clínicas, Fundación Valle del Lili (CO) (CIC 001). Universidad ICESI (CO) (IP-FO-01)

Conflicts of interest Authors declare no conflicts of interest.

Open Access This article is distributed under the terms of the Creative Commons Attribution-NonCommercial 4.0 International License (http://creativecommons.org/licenses/by-nc/4.0/), which permits any noncommercial use, distribution, and reproduction in any medium, provided you give appropriate credit to the original author(s) and the source, provide a link to the Creative Commons license, and indicate if changes were made.

\section{References}

1. Vincent JL, De Backer D (2013) Circulatory shock. N Engl J Med 369:1726-1734
2. Cecconi M, De Backer D, Antonelli M, Beale R, Bakker J, Hofer C, Jaeschke R, Mebazaa A, Pinsky MR, Teboul JL, Vincent JL, Rhodes A (2014)

Consensus on circulatory shock and hemodynamic monitoring. Task force of the European Society of Intensive Care Medicine. Intensive Care Med 40:1795-1815 
3. Bellomo R, Reade MC, Warrillow SJ (2008) The pursuit of a high central venous oxygen saturation in sepsis: growing concerns. Crit Care 12:130

4. Yealy DM, Kellum JA, Huang DT, Barnato AE, Weissfeld LA, Pike F, Terndrup T, Wang HE, Hou PC, LoVecchio F, Filbin MR, Shapiro NI, Angus DC, Investigators P (2014) A randomized trial of protocol-based care for early septic shock. N Engl J Med 370:1683-1693

5. Peake SL, Bailey M, Bellomo R, Cameron PA, Cross A, Delaney A, Finfer S, Higgins A, Jones DA, Myburgh JA, Syres GA, Webb SA, Williams P, ARISE Investigators, for the Australian and New Zealand Intensive Care Society Clinical Trials Group (2009) Australasian resuscitation of sepsis evaluation (ARISE): a multicentre, prospective, inception cohort study. Resuscitation 80:811-818

6. Mouncey PR, Osborn TM, Power GS, Harrison DA, Sadique MZ, Grieve RD, Jahan R, Harvey SE, Bell D, Bion JF, Coats TJ, Singer M, Young JD, Rowan KM, Investigators PT (2015) Trial of early, goal-directed resuscitation for septic shock. N Engl J Med 372:1301-1311

7. van Beest PA, Hofstra JJ, Schultz MJ, Boerma EC, Spronk PE, Kuiper MA (2008) The incidence of low venous oxygen saturation on admission to the intensive care unit: a multi-center observational study in the Netherlands. Crit Care 12:R33

8. Ospina-Tascón GA, Bautista-Rincón DF, Umaña M, Tafur JD, Gutiérrez A, García AF, Bermúdez W, Granados M, Arango-Dávila C, Hernández G (2013) Persistently high venous-to-arterial carbon dioxide differences during early resuscitation are associated with poor outcomes in septic shock. Crit Care 17:R294

9. van Beest PA, Lont MC, Holman ND, Loef B, Kuiper MA, Boerma EC (2013) Central venous-arterial $\mathrm{pCO}_{2}$ difference as a tool in resuscitation of septic patients. Intensive Care Med 39:1034-1039

10. Vallée F, Vallet B, Mathe O, Parraguette J, Mari A, Silva S, Samii K, Fourcade O, Genestal M (2008) Central venous-to-arterial carbon dioxide difference: an additional target for goaldirected therapy in septic shock? Intensive Care Med 34:2218-2225

11. Grundler W, Weil MH, Rackow EC (1986) Arteriovenous carbon dioxide and $\mathrm{pH}$ gradients during cardiac arrest. Circulation 74:1071-1074
12. Weil MH, Rackow EC, Trevino R, Grundler W, Falk JL, Griffel MI (1986) Difference in acid-base state between venous and arterial blood during cardiopulmonary resuscitation. N Engl J Med 315:153-156

13. Zhang H, Vincent JL (1993)

Arteriovenous differences in $\mathrm{PCO} 2$ and $\mathrm{pH}$ are good indicators of critical hypoperfusion. Am Rev Respir Dis 148:867-871

14. Van der Linden P, Rausin I, Deltell A, Bekrar Y, Gilbart E, Bakker J, Vincent JL (1995) Detection of tissue hypoxia by arteriovenous gradient for PCO2 and $\mathrm{pH}$ in anesthetized dogs during progressive hemorrhage. Anesth Analg 80:269-275

15. Groeneveld AB, Vermeij CG, Thijs LG (1991) Arterial and mixed venous blood acid-base balance during hypoperfusion with incremental positive endexpiratory pressure in the pig. Anesth Analg 73:576-582

16. Teboul JL, Mercat A, Lenique F, Berton C, Richard C (1998) Value of the venous-arterial $\mathrm{PCO} 2$ gradient to reflect the oxygen supply to demand in humans: effects of dobutamine. Crit Care Med 26:1007-1010

17. Bakker J, Vincent JL, Gris P, Leon M, Coffernils M, Kahn RJ (1992) Venoarterial carbon dioxide gradient in human septic shock. Chest 101:509-515

18. Mecher CE, Rackow EC, Astiz ME, Weil MH (1990) Venous hypercarbia associated with severe sepsis and systemic hypoperfusion. Crit Care Med 18:585-589

19. Vallet B, Teboul JL, Cain S, Curtis S (2000) Venoarterial CO(2) difference during regional ischemic or hypoxic hypoxia. J Appl Physiol 89:1317-1321

20. Dubin A, Estenssoro E, Murias G, Pozo MO, Sottile JP, Barán M, Piacentini E, Canales HS, Etcheverry G (2004) Intramucosal-arterial $\mathrm{PCO}_{2}$ gradient does not reflect intestinal dysoxia in anemic hypoxia. J Trauma 57:1211-1217

21. De Backer D, Creteur J, Preiser JC, Dubois MJ, Vincent JL (2002) Microvascular blood flow is altered in patients with sepsis. Am J Respir Crit Care Med 166:98-104

22. De Backer D, Ospina-Tascon G, Salgado D, Favory R, Creteur J, Vincent JL (2010) Monitoring the microcirculation in the critically ill patient: current methods and future approaches. Intensive Care Med 36:1813-1825
23. Sakr Y, Dubois MJ, De Backer D, Creteur J, Vincent JL (2004) Persistent microcirculatory alterations are associated with organ failure and death in patients with septic shock. Crit Care Med 32:1825-1831

24. Creteur J, De Backer D, Sakr Y, Koch M, Vincent JL (2006) Sublingual capnometry tracks microcirculatory changes in septic patients. Intensive Care Med 32:516-523

25. Dubin A, Edul VS, Pozo MO, Murias G, Canullan CM, Martins EF, Ferrara G, Canales HS, Laporte M, Estenssoro E, Ince C (2008) Persistent villi hypoperfusion explains intramucosal acidosis in sheep endotoxemia. Crit Care Med 36:535-542

26. Horan TC, Andrus M, Dudeck MA (2008) CDC/NHSN surveillance definition of health care-associated infection and criteria for specific types of infections in the acute care setting. Am J Infect Control 36:309-332

27. Levy MM, Fink MP, Marshall JC, Abraham E, Angus D, Cook D, Cohen J, Opal SM, Vincent JL, Ramsay G, SCCM/ESICM/ACCP/ATS/SIS (2003) $2001 \mathrm{SCCM} / \mathrm{ESICM} / \mathrm{ACCP} / \mathrm{ATS} / \mathrm{SIS}$ International Sepsis Definitions Conference. Crit Care Med 31:1250-1256

28. Dellinger RP, Levy MM, Rhodes A, Annane D, Gerlach H, Opal SM, Sevransky JE, Sprung CL, Douglas IS, Jaeschke R, Osborn TM, Nunnally ME, Townsend SR, Reinhart K, Kleinpell RM, Angus DC, Deutschman CS, Machado FR, Rubenfeld GD, Webb SA, Beale RJ, Vincent JL, Moreno R, Surviving Sepsis Campaign Guidelines Committee including The Pediatric Subgroup (2013) Surviving Sepsis Campaign: international guidelines for management of severe sepsis and septic shock, 2012. Crit Care Med 41:580-637

29. De Backer D, Hollenberg S, Boerma C, Goedhart P, Büchele G, Ospina-Tascon G, Dobbe I, Ince C (2007) How to evaluate the microcirculation: report of a round table conference. Crit Care 11:R101

30. Wu L, Tiwari MM, Messer KJ, Holthoff JH, Gokden N, Brock RW, Mayeux PR (2007) Peritubular capillary dysfunction and renal tubular epithelial cell stress following lipopolysaccharide administration in mice. Am J Physiol Renal Physiol 292:F261-F268

31. Fink T, Heymann P, Taha-Melitz S, Taha A, Wolf B, Rensing H, Volk T, Mathes AM (2013) Dobutamine pretreatment improves survival, liver function, and hepatic microcirculation after polymicrobial sepsis in rat. Shock 40:129-135 
32. Bateman RM, Tokunaga C, Kareco T, Dorscheid DR, Walley KR (2007) Myocardial hypoxia-inducible HIF1alpha, VEGF, and GLUT1 gene expression is associated with microvascular and ICAM-1 heterogeneity during endotoxemia. Am J Physiol Heart Circ Physiol 293:H448H456

33. De Backer D, Donadello K, Sakr Y, Ospina-Tascon G, Salgado D, Scolletta S, Vincent JL (2013) Microcirculatory alterations in patients with severe sepsis: impact of time of assessment and relationship with outcome. Crit Care Med 41:791-799

34. Moore JP, Dyson A, Singer M, Fraser J (2015) Microcirculatory dysfunction and resuscitation: why, when, and how. Br J Anaesth 115:366-375

35. Ince C (2014) The rationale for microcirculatory guided fluid therapy. Curr Opin Crit Care 20:301-308

36. Zuurbier $C J$, van Iterson $M$, Ince $C$ (1999) Functional heterogeneity of oxygen supply-consumption ratio in the heart. Cardiovasc Res 44:488-497

37. Stein JC, Ellis CG, Ellsworth ML (1993) Relationship between capillary and systemic venous PO2 during nonhypoxic and hypoxic ventilation. Am J Physiol 265:H537-H542

38. Goldman D, Bateman RM, Ellis CG (2006) Effect of decreased $\mathrm{O}_{2}$ supply on skeletal muscle oxygenation and $\mathrm{O}_{2}$ consumption during sepsis: role of heterogeneous capillary spacing and blood flow. Am J Physiol Heart Circ Physiol 290:H2277-H2285
39. Walley KR (1996) Heterogeneity of oxygen delivery impairs oxygen extraction by peripheral tissues: theory. J Appl Physiol 81:885-894

40. De Backer D, Creteur J, Dubois MJ, Sakr Y, Koch M, Verdant C, Vincent JL (2006) The effects of dobutamine on microcirculatory alterations in patients with septic shock are independent of its systemic effects. Crit Care Med 34:403-408

41. Edul VS, Enrico C, Laviolle B, Vazquez AR, Ince C, Dubin A (2012) Quantitative assessment of the microcirculation in healthy volunteers and in patients with septic shock. Crit Care Med 40:1443-1448

42. Ospina-Tascon GA, Umana M, Bermudez W, Bautista-Rincon DF, Hernandez G, Bruhn A, Granados M, Salazar B, Arango-Davila C, De Backer D (2015) Combination of arterial lactate levels and venous-arterial $\mathrm{CO}_{2}$ to arterial-venous $\mathrm{O}_{2}$ content difference ratio as markers of resuscitation in patients with septic shock. Intensive Care Med 41:796-805

43. Jakob SM, Groeneveld AB, Teboul JL (2015) Venous-arterial $\mathrm{CO}_{2}$ to arterialvenous $\mathrm{O}_{2}$ difference ratio as a resuscitation target in shock states? Intensive Care Med 41:936-938

44. Cuschieri J, Rivers EP, Donnino MW, Katilius M, Jacobsen G, Nguyen HB, Pamukov N, Horst HM (2005) Central venous-arterial carbon dioxide difference as an indicator of cardiac index. Intensive Care Med 31:818-822
45. Vandenbroucke JP (2008) Observational research, randomised trials, and two views of medical science. PLoS Med 5:e67

46. Pearce N (2011) Registration of protocols for observational research is unnecessary and would do more harm than good. Occup Environ Med 68:86-88 